\title{
Analisis Isi Berita Kegiatan Corporate Social Responsibility PT. PLN (Persero) Distribusi Jawa Tengah dan D.I.Y serta Hubungannya dengan Citra Perusahaan
}

\author{
Revita Tri Sulastri dan Heni Indrayani \\ Universitas Dian Nuswantoro \\ revitatrisulastri@gmail.com
}

\begin{abstract}
Abstrak
Persaingan antar perusahaan yang ketat menuntut perusahaan untuk menjadi yang terdepan dan mendapatkan penilaian positif dari masyarakat yang berujung dengan peningkatan citra perusahaan. Perusahaan berlomba-lomba berusaha menyenangkan masyarakat dan stakeholder dengan melakukan hal- hal positif, inovatif dan menunjukkan prestasi-prestasi yang baik kepada publik. Salah satu caranya adalah melaksanakan kegiatan Corporate Social Responsibility sekaligus sebagai ajang presentasi diri. Hal ini berkaitan erat dengan teori Manajemen Impresi dalam lingkup profesional organisasi dimana perusahaan berusaha untuk menyebarkan hal positif saja. Penelitian ini bertujuan untuk mengukur signifikansi hubungan Corporate Social Responsibility yang dilakukan PT. PLN (Persero) Distribusi Jawa Tengah dan D.I.Y dengan Citra Perusahaan melalui pemberitaan di media massa online Tribunjateng.com menggunakan tipe penelitian eksplanatif untuk menjelaskan hubungan dan deskriptif untuk menjelaskan kecenderungan isi. Dengan menggunakan metode kuantitatif dan pendekatan analisis isi, peneliti berusaha menguji sebuah hipotesis melalui sistem SPSS dengan Uji Hubungan yaitu Koefisien Kontingensi dan Uji Statistik Chi-Square terhadap 28 berita terkait kegiatan CSR PT. PLN (Persero) Distribusi Jawa Tengah dan D.I.Y. Hasil penelitian mengungkapkan kecenderungan isi berita pada variabel CSR paling banyak membahas Program CSR dengan persentasi 46,4\% sebanyak 13 berita. Sedangkan pada variabel Citra Perusahaan, kecenderungan isi berita pada indikator Reputation dengan 19 berita dan persentasi 67,8\%. Kekuatan hubungan antara dua variabel sangat lemah diketahui berdasarkan hasil Koefisien Kontingensi sebesar 0,238. Hasil penelitian juga menunjukkan tidak adanya hubungan antara kegiatan CSR dengan Citra Perusahaan dengan Probabilitas Asymp. Sig dan Approx Sig. sebesar $0,642>0,05$ sehingga $\mathrm{H}_{0}$ diterima.
\end{abstract}

Kata Kunci : Corporate Social Responsibility, Citra, Media Online, Manajemen Impresi

\begin{abstract}
Intense company competition requires the company to be at the forefront and get positive ratings from the community that culminate with the improvement of the company's image. Companies are competing to please the public and stakeholders by doing positive things, innovative and showing good achievements to the public. One way is to carry out Corporate Social Responsibility activities as well as a self presentation event. This is closely related to the theory of Impression Management within the professional scope of the organization in which the company strives to spread positive things. This study aims to measure the significance of Corporate Social Responsibility News relationship conducted by PT. PLN (Persero) Central Java and D.I.Y Distribution to Corporate Image through the news in online mass media Tribunjateng. com using explanative type of research. By using quantitative method and content analysis approach, the researcher tried to test a hypothesis through SPSS system with Contingency
\end{abstract}


Coefficient technique and Chi-Square formula to 28 news related PLN CSR activities. The results revealed the tendency of news content on CSR variables most discussed CSR Program with 46.4\% percentage of 13 news. While on Corporate Image variable, the tendency of news content on Reputation indicator with 19 news and percentage 67,8\%. The strength of the relationship between two variables is very week based on the results of the Contingency Coefficient value is 0,238 . The result of the research also shows that there is no correlation between CSR activities with Corporate Image with probability Asymp. Sig and Approx Sig.0,642 > 0,05 so that $H_{0}$ is accepted.

Keywords: Corporate Social Responsibility, Image, Online Media, Impression Management

\section{Pendahuluan}

Bagi sebuah perusahaan, citra yang baik merupakan hal penting untuk mempertahankan keberhasilan dan tujuan perusahaan. Citra dapat dikatakan sebagai persepsi masyarakat dari adanya pengalaman, kepercayaan, perasaan, dan pengetahuan masyarakat itu sendiri terhadap perusahaan, sehingga aspek fasilitas yang dimiliki perusahaan dan layanan yang disampaikan karyawan kepada konsumen dapat mempengaruhi persepsi konsumen terhadap citra (Jefkins,2003:93). Citra bagi sebuah perusahaan dapat memberikan kemudahan bagi perusahaan itu sendiri untuk berkomunikasi dan mencapai tujuan secara efektif terhadap masyarakat. Citra mencerminkan persepsi publik atau masyarakat terhadap tindakan- tindakan perusahaan yang telah dilakukan.Sikap publik terhadap citra perusahaan dapat berubah sewaktu-waktu tergantung dengan pengalaman ataupun informasi yang diterima. Itulah mengapa citra dibangun tidak secara instan namun harus dibentuk secara terus - menerus agar dapat tumbuh dan melekat di hati masyarakat dan para stakeholder. Pada akhirnya, sikap publik terhadap sebuah organisasi di masa depan akan bergantung pada informasi yang diperoleh mengenai organisasi di masa lalu. Tindakan positif suatu perusahaan hendaknya terpublikasikan dengan baik agar terus menerus menjadi informasi yang mempengaruhi persepsi publik. Frank Jefkins dalam buku "Public Relations" Essential of Public Relations (Yadin, 2003:20-22) menerangkan citra perusahaan sebagai berikut:

"Citra perusahaan (corporate image) adalah citra dari suatu organisasi atau perusahaan secara keseluruhan. Suatu badan usaha yang memiliki citra perusahaan yang positif lebih mudah menjual produk dan jasanya."

Citra dapat membantu sebagian orang untuk menilai atau menyimpulkan suatu produk, kegiatan, maupun nama perusahaan sebagaimana yang mereka lihat, dengar, atau rasakan. Dengan memiliki citra yang baik, perusahaan akan lebih mudah menjual produk atau jasanya dikarenakan pandangan publik telah terbentuk dengan baik. Sebagaimana disebutkan diatas, bahwa citra tidak hadir secara instan, perusahaan harus memiliki cara-cara untuk membangun sebuah citra yang baik, salah satunya melalui berbagai atribut seperti melalui kegiatan 
perusahaan agar nantinya diolah menjadi informasi yang dapat disebarluaskan kepada publik.

Sebuah perusahaan sebisa mungkin menghindari berita-berita negatif dengan menampilkan gambaran perusahaan atau konsep perusahaannya sebaik mungkin demi mencapai atau memelihara citra. Upaya ini disebut Manajemen Impresi. Dalam Manajemen Impresi, individu secara sengaja menggunakan komunikasi untuk menciptakan impresi yang diinginkan dari orang lain terhadapnya (Kriyantono, 2017:220). Manajemen Impresi juga diaplikasikan dalam praktek profesional yaitu dalam sebuah organisasi atau perusahaan. Dalam pengaplikasian di organisasi, terdapat atribut atau simbol yang digunakan untuk presentasi diri yaitu menyenangkan orang lain, promosi diri, menjadi contoh, memiliki keterbatasan dan mengontrol situasi (Kriyantono, 2017:223). Atribut atau simbol ini dapat berupa tindakan dari perusahaan dalam menanggapi sesuatu, atau kegiatan perusahaan untuk ajang promosi diri.

Dalam salah satu atribut menyenangkan orang lain (strategi ingratiation), perusahaan berusaha menampilkan emosi-emosi positif selama interaksi dengan publik, salah satunya organisasi suka membantu publik. Salah satu contoh atribut dari strategi ingratiation ini berupa kegiatan perusahaan yang dekat dengan masyarakat yaitu kegiatan Corporate Social Responsiblity (CSR). Corporate Social Responsibility atau yang biasa disebut CSR, merupakan suatu bentuk komitmen perusahaan untuk memberikan kontribusi yang lebih kepada masyarakat melalui tindakan sosial maupun tanggung jawab lingkungan. Dalam ISO 26000, CSR meliputi tujuh komponen utama, yaitu: the environment, social development, human rights, organizational governance, labor practices, fair operating practices, and consumer issues.

CSR dinyatakan dalam Undang-Undang Perseroan Terbatas (UUPT) Pasal 74 No.40 Tahun 2007 disebutkan bahwa "Perseroan yang menjalankan kegiatan usahanya di bidang dan/atau berkaitan dengan sumber daya alam wajib melaksanakan tanggung jawab sosial dan lingkungan". Peraturan mengenai CSR tidak hanya diatur dalam Pasal 74 UUPT namun juga di dalam pasal 15 Undang-Undang Nomor 25 Tahun 2007 tentang Penanaman Modal (UUPM). Pada UUPM, Perseroan yang tidak melaksanakan CSR diatur dalam Pasal 34 UUPM yaitu dikenakan sanksi administratif berupa peringatan tertulis, pembatasan kegiatan, pencabutan kegiatan dan usaha dan/atau fasilitas penanaman modal. Sedangkan dalam UUPT ketentuan sanksi bagi Perseroan yang tidak melaksanakan kewajiban CSR tidak diatur secara spesifik, melainkan diserahkan dan dikenai sanksi yang sesuai dengan peraturan perundang-undangan terkait, yaitu dikenai segala bentuk sanksi yang diatur dalam peraturan perundang- undangan tersebut.

Hal diatas disampaikan pula oleh Menteri Desa Pembangunan Daerah Tertinggal, dan Transmigrasi Marwan Jafar dalam keterangan resmi yang dikutip oleh Republika.co.id. Pemerintah melakukan verifikasi CSR kepada beberapa perusahaan dikarenakan masih banyaknya keluhan warga yang tidak mendapatkan bantuan apapun dari industri di sekitar mereka. Padahal kegiatan CSR yang baik akan meningkatkan nilai tambah pula kepada daerah daerah tersebut (Abaikan CSR, Marwan Ganjar Sanksi BagiPerusahaan,http://www.republika. 
co.id, diakses pada 4 Maret 2018).

Corporate Social Responsibility pada akhirnya menjadi salah satu indikator kinerja perusahaan yang dapat memunculkan good image di kalangan masyarakat. Hal ini dapat membantu perusahaan tersebut untuk mendapatkan citra yang baik di mata masyarakat luas sehingga dapat menarik investor maupun kerjasama dengan para stakeholder. Pelaksanaan program CSR merupakan upaya untuk menyelaraskan strategi bisnis perusahaan dengan program-program berkesinambungan yang mengacu pada kebutuhan masyarakat. Apabila perusahaan melakukan kegiatan yang positif dan bermanfaat bagi banyak pihak, maka perusahaan tersebut akan mendapatkan feedback yang positif pula. Sutojo (2004:3) mengemukakan bahwa terbentuknya citra positif sebagai akibat pelaksanaan CSR oleh suatu perusahaan akan membawa dampak pada keberhasilan kegiatan bisnis dan pemasaran perusahaan. Dalam jangka panjang, pencitraan positif ini akan membawa banyak manfaat bagi perusahaan pelaku CSR, baik pada saat perusahaan sedang mengalami masa kejayaan maupun pada saat menghadapi berbagai masalah krisis.

Namun, kegiatan CSR perlu dikomunikasikan dan dipertanggung jawabkan kepada masyarakat. Hal ini merupakan tugas pokok perusahaan. Pembentukan citra yang positif tergantung informasi dan pengalaman yang terus menerus diterima oleh masyarakat. Para stakeholder dan masyarakat harus mengetahui kegiatan CSR apa saja yang telah dilakukan oleh suatu perusahaan. Semakin banyak masyarakat tahu, maka kegiatan CSR akan semakin bermanfaat dan dapat meningkatkan citra perusahaan. Dalam pengkomunikasian kegiatan CSR terdapat beberapa cara yang sering digunakan seperti berita, pemberitaan media, iklan, laporan tahunan dan laporan berkelanjutan di situs web resmi perusahaan dan lain-lain. Publikasi pemberitaan kegiatan perusahaan merupakan salah satu cara untuk membangun informasi kepada masyarakat melalui media massa baik konvensional maupun online. Salah satu perusahaan yang menerapkan hal tersebut ialah PT. PLN (Persero) Distribusi Jawa Tengah dan D.I.Y.

PT. PLN (Persero) Distribusi Jawa Tengah dan D.I.Y merupakan salah satu perusahaan negara yang rutin melaksanakan kegiatan CSR dan mempublikasikannya di media massa online. Penggunanaan media massa online dikarenaan jangkauan yang luas dan lebih mudah diakses oleh siapa saja. Perusahaan ini membagi berbagai kegiatan CSR kedalam beberapa kategori yaitu Pelestarian Alam \& Peduli Lingkungan; Sosial dan Pengentasan Kemiskinan; Bencana Alam; Pendidikan dan Pelatihan; Peningkatan Kesehatan; Pengembangan Sarana Umum; dan Sarana Ibadah dan Kegiatan Keagamaan. Hal ini sesuai dengan visi PLN Peduli untuk mewujudkan keharmonisan hubungan PLN dengan masyarakat sehingga akan menunjang keberhasilan PT.PLN (Persero) itu sendiri dalam pemenuhan kebutuhan listrik masyarakat. Kegiatan program CSR ini pun disebutkan dalam Surat keputusan Direksi PT.PLN (Persero) Nomor. 366.K/DIR/2007 tanggal 28 Desember 2017 tentang tertib administrasi Program Bina Lingkungan. 
Sebagai salah satu perusahaan besar, PT.PLN (Persero) Distribusi Jawa Tengah dan D.I.Y berusaha untuk melakukan program CSR dengan baik. Hal ini terlihat dengan banyaknya penghargaan yang telah di dapat diantaranya adalah PLN CSR Award 2016 di lingkungan PLN secara Nasional, Indonesia Green Award 2017 dengan kategori Penyelamatan Sumber Daya Air dengan Program CSR Menjaga Sumber Air Sungai Mudal oleh The La Tofi School of CSR, 3 Penghargaan Nusantara CSR Award 2017 dalam kategori Peningkatan Mutu Pendidikan Masyarakat, Peningkatan Ekonomi Masyarakat dan Peningkatan Mutu Kesehatan Masyarakat oleh The La Tofi School of CSR serta meraih predikat Gold dalam CSR Award 2017 kategori Bidang Pelibatan dan Pengembangan Masyarakat oleh Kementrian Riset Teknologi dan Pendidikan Tinggi.

Kegiatan CSR oleh PLN Distribusi Jawa Tengah tentu tidak lepas dari peran sorotan media. Media memiliki peran-peran tertentu untuk menonjolkan kegiatan CSR PLN Distribusi Jawa Tengah dan D.I.Y dan mengkomunikasikannya kepada masyarakat luas. Ini disebut dengan publisitas sebagai hasil hubungan dekat media dengan perusahaan melalui public relation. Menurut Philip dan Herbert M. Baus dalam Ruslan (2008:60) menyatakan publikasi (publication) merupakan tugas public relations dalam menceritakan atau menyampaikan sebanyak mungkin pesan atau informasi mengenai kegiatan perusahaan kepada masyarakat luas. Peran media mampu mengajak masyarakat untuk menginterpretasikan peristiwa yang disampaikan. Dengan terus menerus terpapar informasi positif, bukan tidak mungkin adanya pembentukan kesan ataupun persepsi yang positif pula bagi masyarakat. Ada banyak cara dalam mempublikasikan sebuah kegiatan perusahaan, salah satunya melalui media massa online.

Kegiatan CSR PT.PLN (Persero) Distribusi Jawa Tengah dan D.I.Y sering kali dipublikasikan melalui berita-berita online salah satunya Tribun Jateng. Tribun Jateng secara konsisten memberitakan kegiatan CSR PLN di wilayah Jawa Tengah salah satunya mengenai Program PLN Peduli yang menggelontorkan CSR hingga Rp 400 Juta untuk mendorong kemajuan pariwisata di Kabupaten Batang. Bahkan Deputi Manajer Komunikasi dan Bina Lingkungan PT PLN (Persero) Distribusi Jateng dan D.I.Y, Hadian Sakti Laksana, mengatakan akan menyalurkan CSR sekitar Rp 9 Miliar selama tahun 2017 (PLN Salurkan Rp.400 Juta untuk Dorong Tiga Tempat Wisata Ini,http://jateng.tribunnews.com, diakses pada 4 Maret 2018)

Konsistensi Tribun Jateng dalam pemberitaan mengenai CSR PT. PLN (Persero) Jawa Tengah dan D.I.Y terlihat selama tahun 2017 hingga kuartal pertama tahun 2018. Dalam satu tahun tiga bulan, Tribun Jateng merupakan media online yang paling banyak memuat berita CSR PLN dibandingkan dengan media online daerah lainnya seperti Suaramerdeka.com, Kedaulatan Rakyat atau krjogja.com, dan Jatengpos.com.

Adapun peneliti membuat perbandingan banyaknya berita di media online Jatengpos. 
com, Suaramerdeka.com, Kedaulatan Rakyat atau krjogja.com dan Tribunjateng.com dalam kurun waktu selama tahun 2017 hingga kuartal pertama tahun 2018. Peneliti mengambil empat media online tersebut karena keempat media ini merupakan media online daerah yang biasanya memuat berita seputar Jawa Tengah dan telah bekerja sama dengan PT. PLN (Persero) Distribusi Jawa Tengah dan D.I.Y seperti yang telah dikemukakan oleh Dian, Humas PT. PLN (Persero) Distribusi Jawa Tengah dan D.I.Y. Berikut merupakan bagan perbandingan jumlah berita :

Gambar 1 Jumlah Berita CSR PLN Distribusi Jateng- D.I.Y di Media Online Januari 2017 - Maret 2018

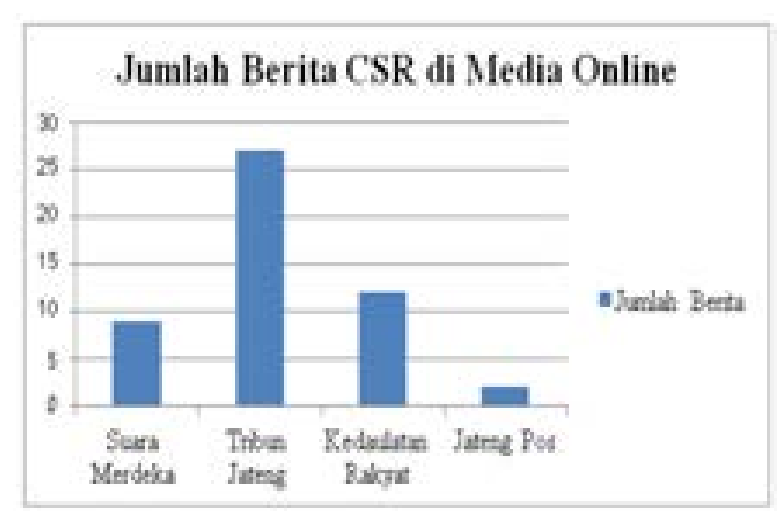

sumber : Olah Data Peneliti

Dari gambar 1 menunjukkan bahwa dalam satu tahun tiga bulan Suaramerdeka.com memuat 9 berita, Tribunjateng.com dengan 28 berita, Kedaulatan Rakyat atau krjogja.com sebanyak 12 berita dan Jatengpos.com dengan 2 berita. Hal ini membuktikan Tribunjateng.com secara konsisten memberitakan berita CSR PT. PLN (Persero) Distribusi Jateng \&D.I.Y dibanding 3 media online daerah lainnya.

Dari uraian diatas, PT. PLN (Persero) Distribusi Jawa Tengah dan D.I.Y melakukan program Corporate Social Responsibility dengan baik terbukti dengan penghargaan yang didapat. Hal ini juga disampaikan dan dipublikasikan melalui media online kepada masyarakat. Penerapan program Corporate Social Responsibility oleh PLN merupakan suatu bentuk tanggung jawab yang harus dilakukan untuk memperbaiki masalah-masalah sosial seperti kesehatan dan kesejahteraan masyarakat serta lingkungan yang terjadi akibat aktivitas operasional yang dilakukan perusahaan. Semakin baik dampak dari pertanggungjawaban yang dilakukan perusahaan, maka citra perusahaan akan semakin baik dimata masyarakat dan stakeholder. Implementasi yang telah dilakukan oleh perusahaan dan respon masyarakat dapat diketahui langsung melalui peran Humas suatu perusahaan salah satunya adalah berita/publikasi berita mengenai kegiatan - kegiatan positif perusahaan. Hal ini sudah sewajarnya dikarenakan publikasi berita yang positif merupakan simbol atau atribut untuk mempresentasikan 
diri. Perusahaan berusaha selalu menampilkan image positif melalui kegiatan-kegiatan yang dilakukan. Publikasi sebuah kegiatan positif di media online merupakan suatu bentuk pelaporan kepada masyarakat sebagai upaya presentasi diri untuk mendapatkan legitimasi citra baik. Seperti yang diterangkan menurut Fauset dalam Butterick (2012:98) bahwa CSR dapat membantu memunculkan citra seperti suatu perusahaan peduli pada lingkungan dan untuk menutupi dampak negatif, perusahaan memenuhi media dengan citra positif tentang pesan CSR perusahaan. Hal ini menjadi alasan peneliti untuk melakukan penelitian terkait pengaruh pemberitaan CSR PLN dikarenakan PT. PLN (Persero) Distribusi Jawa Tengah dan D.I.Y merupakan perusahaan yang bersentuhan secara langsung dengan masyarakat. Peneliti ingin mengkaji lebih dalam bagaimana citra perusahaan ini dimata masyarakat dalam menjalankan programnya melalui isi berita sebuah media. Peneliti mengambil penelitian isi berita di Tribunjateng.com karena banyaknya berita CSR yang termuat di media online tersebut lebih banyak dibandingkan dengan media online daerah lainnya. Tentu saja hal itu dapat mendukung penelitian ini sehingga memudahkan peneliti dalam mengolah data. Oleh karena itu, rumusah masalah dalam penelitian ini adalah "Apa kecenderungan isi berita mengenai kegiatan Corporate Social Responsibility PT. PLN (Persero) Distribusi Jawa Tengah dan D.I.Y serta hubungan antara berita kegiatan CSR dengan Citra Perusahaan yang terpresentasi dalam media online Tribunjateng.com ?"

\section{Tujuan Penelitian}

1. Untuk Mengetahui kecenderungan isi pesan mengenai kegiatan Corporate Social Responsibility (CSR) PT PLN (Persero) Distribusi Jawa Tengah dan D.I.Y yang terpresentasi dalam media online tribunjateng.com

2. Untuk mengetahui kecenderungan isi pesan yang terkait dengan indikator Citra Perusahaan pada berita CSR di media online tribunjateng.com

3. Mengetahui hubungan pemberitaan CSR di Media Online Tribunjateng.com dalam peningkatan citra perusahaan PT.PLN (Persero) Distribusi Jawa Tengah dan D.I.Y

\section{Kerangka Teori}

\subsection{Manajemen Impresi}

Impression Management atau Manajemen Impresi yang lebih dikenal dengan istilah pengelolaan kesan sering kali dilakukan oleh orang-orang yang memiliki profesi dan dituntut untuk memiliki self image yang positif. Menurut uraian West \& Turnet (2008:146), Manajemen Impresi (Impression Management) di definisikan sebagai aktivitas seseorang agar terlihat baik bagi orang lain serta dirinya sendiri. Sedangkan teori Manajemen Impresi (Impression 
Management) menurut Johansson dalam Kriyantono (2014:220) adalah dalam setiap interaksi sosial setiap individu berupaya menampilkan gambaran dirinya atau konsep dirinya di depan orang lain. Upaya ini disebut manajemen impresi, yaitu individu secara sengaja menggunakan komunikasi untuk menciptakan impresi yang di inginkan dari orang lain terhadap dirinya.

Manajemen impresi ini juga dapat mengacu pada praktek dalam komunikasi profesional seperti yang terjadi dalam lingkungan perusahaan. Untuk meraih citra yang baik, perusahaan juga harus mampu memainkan peran di depan masyarakat agar citra yang dibentuk oleh perusahaan sesuai pula dengan yang dipersepsikan oleh masyarakat. Walau bagaimanapun, segala kegiatan, tindakan, hubungan yang baik dengan stakeholder dan kerjasama dengan masyarakat merupakan upaya perusahaan untuk mencapai suatu tujuan yaitu citra yang baik. Sebagaimana menurut Stanton yang dikutip dalam Mutmainah (2011:242) sebagai suatu konsep sosial, manajemen impresi adalah upaya untuk mengontrol image baik nyata maupun imajinasian dalam interaksi sosial. Manajemen impresi dapat diaplikasikan dalam situasi apapun saat representasi organisasi bertindak sebagai gatekeeper informasi dan akan mempengaruhi perilaku opini serta perilaku audiens. Karenanya manajemen impresi merupakan upaya rasional dari komunikasi perusahaan yang dikontrol dan dikelola, serta bersifat mempengaruhi dan persuasif. Image yang memiliki nilai-nilai ekspektasi positif diungkap, sedangkan image bernilai negatif dihindari (Gardner dan Martinko dalam Mutmainah, 2011 :242).

Dalam pengaplikasian manajemen impresi, seorang individu dan organisasi menggunakan simbol atau atribut untuk mempresentasikan diri mereka. Edward Jones mengaplikasikan konsep presentasi diri untuk menjelaskan hubungan antara perilaku individu di depan publik dan motif di balik perilaku itu. Edward Jones (dalam Kriyantono, 2017:222) membuat lima tipologi presentasi (dikutip di Metts, 2009) yang terdiri atas:

a. Strategi ingratiation (menyenangkan orang lain), digunakan oleh organisasi yang ingin dipersepsi sebagai pihak yang menyenangkan atau ramah (friendly) dengan menampilkan emosi-emosi positif saat interaksi dengan publik.

b. Strategi self-promotion (promosi diri), organisasi berusaha menampilkan prestasi yang telah dicapai, hal-hal baik yang telah dilakukan organisasi terhadap publik, dan menampilkan berbagai penghargaan yang diperoleh organisasi atas prestasi. Organisasi ingin menunjukkan bahwa mereka adalah organisasi yang kompeten.

c. Strategi exemplification (sebagai contoh), organisasi berusaha atau ingin dipersepsi sebagai contoh atau model bagi organisasi lain dengan mendemonstrasikan kemampuan, kelebihan, integritas dan nilai-nilai organisasi.

d. Strategi supplication, organisasi ingin dipersepsi sebagai organisasi yang memiliki keterbatasan dalam membantu publik. Sebuah organisasi ingin dipersepsi sebagai pihak yang lemah sekaligus yang menjadi korban dari suatu krisis yang terjadi.

e. Strategi intimidation, sebuah organisasi ingin dipersepsi sebagai organisasi yang 
kuat dan mampu mengontrol situasi diwujudkan dengan menampilkan atribut yang mempresentasikan kemarahan atau keinginan untuk menghukum pihak lain yang menimbulkan kerugian.

\subsection{Berita Corporate Social Responsibility}

Komunikasi CSR menjadi bagian investasi bagi masa depan perusahaan. Kondisi bisnis saat ini menganggap penting implementasi dan komunikasi CSR untuk masa depan perusahaan (Bortree, 2014: 3). Komunikasi CSR berisi pengelolaan informasi mengenai aktivitas CSR untuk pemangku kepentingan. Podnar (2008: 75) mengatakan bahwa komunikasi CSR adalah suatu proses mengantisipasi harapan pemangku kepentingan, artikulasi kebijakan CSR dan mengelola berbagai media komunikasi untuk memberikan informasi yang benar dan transparan tentang integrasi merek perusahaan atau operasi bisnis, sosial dan masalah lingkungan, dan interaksi dengan pemangku kepentingan.

Secara garis besar, komunikasi pemberitaan CSR melalui media mencakup 3 komponen yaitu contents (isi); what to communicate, to whom communicate; audiences (khayalak sasaran), dan by using what channels (channels/media) (Effendy, 2003:253). Berita Corporate Social.Responsibility merupakan salah satu ajang presentasi diri perusahaan untuk menunjukkan kepada masyarakat mengenai hal-hal positif yang telah dilakukan. Menurut Fauset, CSR dapat membantu memunculkan citra suatu perusahaan peduli pada lingkungan dan untuk menutupi dampak negatif dengan memenuhi media dengan citra positif tentang pesan CSR perusahaan. Karena banyak kasus bisnis untuk CSR bergantung pada perusahaan yang dianggap bertanggung jawab secara sosial, CSR akan lebih mudah dan murah digunakan untuk mengalihkan isu daripada mengubah suatu keadaan yang sudah terlanjur buruk (Butterick,K, 2012:98).

\section{Corporate Social Responsibility}

Kegiatan Corporate Social Responsibility atau CSR sendiri bukan hanya mengenai kepentingan bisnis suatu perusahaan untuk mendapatkan citra yang baik saja tetapi juga membantu perekonomian atau pembangunan masyarakat yang ada disekitaran perusahaan atau lebih sebagai tujuan dari pembangunan berkelanjutan. Carol dalam Susanto (2007:32) menggambarkan CSR sebagai sebuah piramida, yang tersusun dari tanggung jawab ekonomi sebagai landasannya, kemudian tanggung jawab hukum, lantas tanggung jawab etika, dan tanggung jawab filantropis berada di puncak piramida.

Sutojo (2004:3) mengemukakan bahwa terbentuknya citra positif sebagai akibat pelaksanaan CSR oleh suatu perusahaan akan membawa dampak pada keberhasilan kegiatan bisnis dan pemasaran perusahaan. Dalam jangka panjang, pencitraan positif ini akan membawa banyak manfaat bagi perusahaan pelaku CSR, baik pada saat perusahaan sedang mengalami masa kejayaan maupun pada saat menghadapi berbagai masalah krisis. 
Menurut Susanto (2007:28) perusahaan yang menjalankan tanggung jawab sosialnya secara konsisten akan mendapatkan dukungan yang luas dari komunitas yang merasakan manfaat dari berbagai aktivitas yang dijalankannya. Penerapan program CSR akan meningkatkan citra perusahaan dan dalam waktu yang panjang akan terakumulasi menjadi reputasi perusahaan.

Jika terjadi ketidakselarasan antara sistem nilai perusahaan dan sistem nilai masyarakat maka perusahaan dapat kehilangan legitimasinya, yang selanjutnya akan mengancam kelangsungan hidup perusahaan (Lindlom dalam Haniffa et al, 2005). Adapun manfaat program CSR dalam Wibisono (2007:99) diantaranya adalah :

a. Bagi perusahaan, terdapat empat manfaat yaitu keberadaan perusahaan dapat tumbuh dan berkelanjutan, perusahaan lebih mudah memperoleh akses terhadap modal (capital), perusahaan dapat mempertahankan sumber daya manusia (human resources) yang berkualitas, dan perusahaan dapat meningkatkan pengambilan keputusan pada hal-hal yang kritis (critical decision making) dan mempermudah pengelolaan manajemen risiko (risk management).

b. Bagi masyarakat, dengan adanya Corporate Social Responsibility yang baik dapat meningkatkan nilai tambah perusahaan di satu daerah. Hal ini dikarenakan perusahaan akan menyerap tenaga kerja masyarakat daerah, serta meningkatkan kualitas sosial di daerah tersebut. Pekerja lokal yang diserap akan mendapatkan perlindungan terhadap hak-haknya sebagai pekerja. Jika terdapat masyarakat adat atau masyarakat lokal, praktek Corporate Social Responsibility akan menghargai tradisi maupun budaya lokal yang ada pada lingkungan masyarakat adat dimana perusahaan melaksanakan praktiknya.

c. Bagi lingkungan, dengan adanya CSR akan mencegah eksploitasi yang berlebihan terhadap SDA serta menjaga kualitas lingkungan dengan menekan tingkat polusi dan bahkan perusahaan terlibat mempengaruhi lingkungannya.

d. Bagi negara, praktik CSR akan mencegah apa yang disebut "corporate misconduct" atau malpraktik bisnis seperti penyuapan pada aparat negara atau aparat hukum yang memicu tingginya korupsi. Selain itu negara akan menikmati pendapatan dari pajak yang wajar (yang tidak digelapkan) oleh perusahaan.

\subsection{Citra}

Menurut Jalaludin Rakhmat dalam Soemirat dan Ardianto (2002:114) citra adalah dunia menurut persepsi. Dalam Collins English Dictionary yang dikutip dalam buku Strategi Public Relations memberikan definisi citra sebagai suatu gambaran tentang mental; ide yang dihasilkan oleh imaginasi atau kepribadian yang ditunjukkan kepada publik oleh seseorang, organisasi, dan sebagainya (Oliver,2007:50). Pengertian lain, citra adalah perasaan, gambaran diri publik terhadap perusahaan, organisasi, atau lembaga; kesan yang dengan sengaja diciptakan dari 
suatu objek, orang atau organisasi (Ardianto,2011:62).

Citra yang dipilih peneliti dalam penelitian ini merupakan sesuatu yang berbentuk abstrak atau tidak berwujud. Citra merupakan apa yang ditampilkan oleh perilaku seseorang dan dinilai oleh orang lain. Citra merupakan bentuk penilaian atau persepsi individu atau kelompok terhadap perilaku indvidu atau kelompok sehingga memunculkan kesan baik ataupun buruk sesuai dengan apa yang dilakukan. Hal ini sesuai dengan definisi citra yang ada pada KBBI yaitu merupakan gambaran yang dimiliki orang banyak mengenai pribadi, perusahaan, organisasi ataupun produk.

Menurut Harrison dalam Mulyadi, (2007:3), citra meliputi 4 elemen sebagai berikut :

1. Personality, keseluruhan karakteristik yang dipahami oleh publik sasaran seperti perusahaan yang dapat dipercaya dan perusahaan mempunyai tanggung jawab sosial.

2. Reputation, hak yang telah dilakukan perusahaan dan diyakini publik sasaran berdasarkan pengalaman sendiri maupun pihak lain seperti kinerja keamanan transaksi sebuah bank. Reputasi adalah persepsi publik mengenai tindakan-tindakan organisasi yang telah berlalu dan prospek organisasi di masa datang, tentunya dibandingkan dengan organisasi sejenis atau pesaing. Reputasi terkait dengan hal yang telah dilakukan perusahaan dan diyakini publik sasaran berdasarkan pengalaman sendiri maupun pihak lain (Fombrun, 1999: 74). Menurut Charles J. Fombrun dalam buku Reputation: Realizing Value from the Corporate Image reputasi dibangun oleh empat elemen antara lain:

a. Kredibilitas, organisasi diharapkan memiliki kredibilitas dalam tiga hal yaitu: organisasi memperlihatkan profitabilitas, dapat mempertahankan stabilitas dan adanya prospek pertumbuhan yang baik.

b. Reliabilitas, organisasi diharapkan dapat selalu menjaga mutu produk atau jasa dan menjamin terlaksananya pelayanan prima yang diterima pelanggan.

c. Trusworthiness, ini adalah harapan para karyawan. Organisasi diharapkan dapat dipercaya, organisasi dapat memberdayakan karyawan dengan optimal dan organisasi dapat menimbulkan rasa memiliki dan kebanggaan bagi karyawan.

d. Responsibility, ini adalah harapan dari para komunitas. Seberapa banyak atau berarti organisasi membantu pengembangan masyarakat sekitar, seberapa peduli organisasi terhadap masyarakat dan menjadi organisasi yang ramah lingkungan.

3. Value, nilai-nilai yang dimiliki suatu perusahaan dengan kata lain, budaya perusahaan seperti manajemen yang peduli terhadap pelanggan, karyawan yang cepat tanggap terhadap permintaan dan keluhan pelanggan.

4. Corporate identity, komponen yang mempermudah pengenalan publik sasaran terhadap perusahaan seperti logo, warna, dan slogan. 


\section{Hipotesis}

\section{Gambar 2 Kerangka Pemikiran}

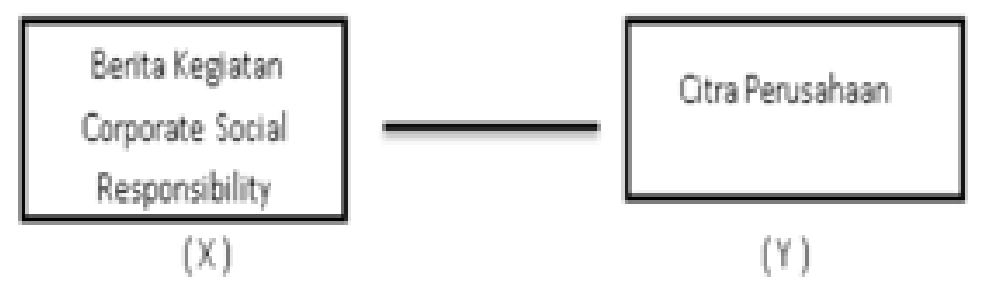

Pada kerangka pemikiran diatas menjelaskan bahwa berita kegiatan Corporate Social Responsibility

(X) memiliki hubungan dengan Citra Perusahaan (Y). Sehingga peneliti mendapatkan hipotesis sebagai berikut :

HO : Tidak ada hubungan antara berita kegiatan CSR dengan citra perusahaan. Ha: Terdapat hubungan antara berita kegiatan CSR dengan citra perusahaan.

\section{Metode Penelitian}

Peneliti menggunakan metode penelitian kuantitatif. Metode penelitian kuantitatif dapat diartikan sebagai metode penelitian yang berlandaskan pada filsafat positivisme, digunakan untuk meneliti pada populasi atau sampel tertentu. Teknik pengambilan sampel umumnya dilakukan secara random, pengumpulan data menggunakan instrumen penelitian, analisis data bersifat kuantitatif/statistik dengan tujuan untuk menguji hipotesis yang telah ditetapkan (Sugiyono, 2012:7). Analisis isi adalah pendekatan ilmiah yang peneliti gunakan. Analisis isi kuantitatif hanya dapat mempertimbangkan "apa yang dikatakan" (what), tetapi tidak dapat menyelidiki "bagaimana ia dikatakan" (how) (Eriyanto, 2011:339). Oleh karena itu, peneliti hanya meneliti apa yang ada di dalam isi berita tanpa mencari tahu bagaimana yang terjadi dibalik berita tersebut. Sedangkan dalam penggunaan tipe penelitiannya, peneliti menggunakan tipe ekspalanatif untuk menjelaskan hubungan dan tipe deskriptif untuk menjelaskan kecenderungan berita. Analisis isi eksplanatif adalah analisis isi yang didalamnya terdapat pengujian hipotesis tertentu.

Pada penelitian ini, populasi yang peneliti ambil adalah semua berita-berita online mengenai kegiatan Corporate Social Responsibility PT. PLN (Persero) Distribusi Jawa Tengah dan D.I.Y pada situs berita tribunjateng.com selama tahun 2017 hingga kuartal pertama tahun 2018. Dari periode tersebut terdapat 28 berita yang membahas mengenai kegiatan CSR PT. PLN (Persero) Distribusi Jawa Tengah dan D.I.Y. Sampel penelitian ini adalah semua berita terkait CSR PT. PLN (Persero) Distribusi Jawa Tengah pada portal berita tribunjateng.com selama tahun 2017 hingga kuartal pertama tahun 2018 yang berjumlah 28 berita. Dalam penelitian 
ini, peneliti menggunakan teknik pengambilan sampel menggunakan total sampling yaitu dimana jumlah sampel sama dengan jumlah populasinya. Hal ini dikarenakan populasi yang dimiliki peneliti kurang dari 100.

\subsection{Teknik Analisa / Interpretasi Data}

Pada penelitian ini, peneliti menggunakan Uji Hubungan dengan Korelasi Koefisien Kontingensi atau Kontingensi $\mathrm{C}$. Rumus dari koefisien kontingensi yaitu :

$$
\mathrm{C}=\overline{\overline{\Gamma^{T}}}
$$

Pada rumus tersebut, $\mathrm{C}$ adalah koefisien kontingensi, $\mathrm{N}$ adalah jumlah sampel dan $\chi 2$ adalah chi kuadrat.

Selanjutnya, peneliti menggunakan Uji Statistik Chi square yang digunakan untuk menguji perbedaan dua sampel independen, dan lebih dari dua sampel baik yang berpasangan ataupun independen. Chi square mempertanyakan mengenai perbedaan frekuensi dan signifikan ataukah hanya terjadi secara kebetulan. Chi Square digunakan untuk menguji probabilitas seperti itu dengan cara mempertentangkan antara frekuensi yang benar-benar terjadi (frekuensi yang dapat di observasi, disebut dengan frekuensi yang diharapkan (disebut E) (Eriyanto, 2011:357). Rumus Chi square adalah sebagai berikut :

$$
x^{2}=\sum \frac{(\mathrm{O}-\mathrm{E})^{2}}{\mathrm{E}}
$$

\section{Hasil Penelitian}

\subsection{Berita Corporate Social Responsibility}

Variabel pertama dalam penelitian ini ialah berita-berita mengenai kegiatan Corporate Social Responsibility (CSR). Peneliti berusaha mengetahui dampak dari implementasi CSR yang dilakukan oleh PT. PLN (Persero) Distribusi Jawa Tengah dan D.I.Y di masyarakat dan opini masyarakat mengenai kegiatan tersebut melalui berita di media online tribunjateng.com. Implementasi CSR dapat dilihat dari indikator berupa tanggung jawab apa yang dilakukan, tujuan perusahaan dalam melakukan CSR, manfaat CSR kepada masyarakat dan program CSR apa saja yang telah dilakukan di masyarakat. Indikator tersebut peneliti deskripsikan dalam tabel matriks berita CSR (4.1) dibawah ini : 
Tabel 1. Matriks Berita CSR

\begin{tabular}{|c|c|c|}
\hline Variabel & Indikstor & Tolak Ukur \\
\hline \multirow{16}{*}{$\begin{array}{l}\text { Berita } \\
\text { Corporote } \\
\text { Sociol } \\
\text { Responsibility }\end{array}$} & \multirow{4}{*}{$\begin{array}{l}\text { a. Tanggung } \\
\text { Jawab }\end{array}$} & 1. Ekonomi \\
\hline & & 2. Hukum \\
\hline & & 3. Etika \\
\hline & & 4 Filantropi \\
\hline & \multirow[t]{4}{*}{ b. Program } & 1. Pendidikan \\
\hline & & 2. Kesehatan \\
\hline & & 3. Sumbangih Sosial \\
\hline & & 4. Pariwisata \\
\hline & \multirow[t]{4}{*}{ c Marfaat } & 1. Akses Terhadap Modal \\
\hline & & 2. Meningkatkan kualitas sosial \\
\hline & & $\begin{array}{l}\text { 3. Meningkatkannilai tambah } \\
\text { perusahaan }\end{array}$ \\
\hline & & 4 Meningkatkankualitas lingkungan \\
\hline & \multirow[t]{4}{*}{ d. Tujuan } & 1. MeningkatkanKesejahteraan \\
\hline & & 2. Menjamin Kesehatanmasyarakat \\
\hline & & 3. Relasi menjadi erat \\
\hline & & 4 Pendidikanmerata \\
\hline
\end{tabular}

Indikator dalam Tabel 1, diatas peneliti ambil melalui asumsi-asumsi teori yang berkenaan dengan Corporate Social Responsibility. Melalui pengkodingan berita dengan tabel matriks dan penggunaan tabel induk (lampiran 1), peneliti berusaha untuk mendapatkan frekuensi banyaknya sebuah indikator terlibat dalam 28 berita CSR. Frekuensi-frekuensi tersebut peneliti deskripsikan sebagai berikut :

\subsection{Tanggung Jawab}

Indikator Tanggung Jawab meliputi tolak ukur hukum, etika, filantropi, dan ekonomi. Penjelasan frekuensi dari masing-masing tolak ukur ialah sebagai berikut :

Tabel 2. Frekuensi Tanggung_Jawab

\begin{tabular}{|c|c|c|c|c|c|}
\hline \multicolumn{2}{|c|}{ Tolak Ukur } & \multirow{2}{*}{$\frac{\text { Frequency }}{7}$} & \multirow{2}{*}{$\frac{\text { Percent }}{25,0}$} & \multirow{2}{*}{$\begin{array}{l}\text { Valid } \\
\text { Percent } \\
25,0\end{array}$} & \multirow{2}{*}{$\begin{array}{l}\text { Cumulative } \\
\text { Percent } \\
25,0\end{array}$} \\
\hline Valid & Ekonomi & & & & \\
\hline & Hukum & 1 & 3,6 & 3,6 & 28,6 \\
\hline & Filantropis & 20 & 71,4 & 71,4 & 100,0 \\
\hline & Total & 28 & 100,0 & 100,0 & \\
\hline
\end{tabular}

Pada tabel 2, hanya menghitung frekuensi seberapa banyak tolak ukur Tanggung Jawab muncul pada setiap berita. Dapat disimpulkan bahwa pada Frekuensi Tanggung Jawab (tabel 3) di dominasi oleh Tanggung Jawab berdasarkan Filantropi dengan 20 berita yang mencapai 
71,4\%. Contoh berita perusahaan yang mencakup tanggung jawab filantropi adalah PLN memberikan bantuan uang dan sembako kepada masyarakat Gunung Pati. Selanjutnya disusul dengan Tanggung Jawab berdasarkan Ekonomi dengan 7 berita sebanyak 25\%. Tanggung jawab ekonomi dimana perusahaan dapat meraih untung sebesar mungkin namun aspek sosialnya juga mampu menyumbang pada ekonomi nasional sehingga dengan sendirinya berkontribusi memakmurkan masyarakat. Salah satu berita yang mewakili tanggung jawab ekonomi ialah upaya PLN untuk membangun Sungai Mudal yang mendapatkan penghargaan.

Tanggung jawab berdasarkan Hukum dengan 1 berita sebanyak 3,6\% serta tidak adanya berita dengan Tanggjung Jawab berdasarkan etika. Pada tanggung jawab hukum perusahaan dituntut agar bisnis yang dilakukan mematuhi hukum dan „bermain dengan aturan main". Salah satu contoh berita yang memuat tanggung jawab hukum adalah berita dimana PLN berusaha untuk menargetkan 6.594 desa teraliri listrik hingga tahun 2019. Ini merupakan suatu kewajiban dan tanggung jawab PT. PLN (Persero) Distribusi Jawa Tengah dan D.I.Y sebagai Perusahaan Listrik Negara yang memang harus memenuhi kebutuhan listrik masyarakat Jawa Tengah.

\subsection{Program CSR}

Adapun hasil frekuensi pada program CSR untuk mengetahui seberapa banyak tolak ukur program untuk pendidikan, kesehatan dan sumbangsih sosial muncul.

Tabel 3. Frekuensi Program_CSR

\begin{tabular}{|l|r|r|r|r|}
\hline \multicolumn{1}{|c|}{ Tolak Ukur } & Frequency & Percent & $\begin{array}{c}\text { Valid } \\
\text { Percent }\end{array}$ & $\begin{array}{c}\text { Cumulative } \\
\text { Percent }\end{array}$ \\
\hline Valid Pendidikan & 5 & 17,9 & 17,9 & 17,9 \\
Kesehatan & 2 & 7,1 & 7,1 & 25,0 \\
Sumbangsih & 17 & 60,7 & 60,7 & 85,7 \\
Sosial & 4 & 14,3 & 14,3 & 100,0 \\
Pariwisata & 28 & 100,0 & 100,0 & \\
Total & &
\end{tabular}

Pada frekuensi Program CSR, program Sumbangsih sosial paling banyak diberitakan mencapai 17 berita dengan persentase $60,7 \%$. Pada program sumbangsih sosial, salah satu berita yang mewakili ialah ketika PT. PLN (Persero) Distribusi Jawa Tengah dan D.I.Y memberikan sedikitnya Rp. 245 juta kepada kebutuhan masyarakat Demak Kemudian berita mengenai program Pendidikan sebanyak 5 berita dengan persentasi 17,9\%. Pada program pendidikan, perusahaan berusaha untuk membantu kualitas pendidikan yang ada di wilayah Jawa Tengah. Perusahaan juga turut aktif untuk meningkatkan kualitas kesehatan dan lingkungan masyarakat. PT.PLN (Persero) Distribusi Jawa Tengah memiliki program unggulan yaitu pembuatan 164 Jamban 
untuk mengatasi masalah sanitasi yang ada di masyarakat. Berita mengenai program kesehatan terdapat 2 berita dengan persentase 7,1\%. Dan terakhir terdapat 4 berita mengenai program pariwisata dengan persentasi $14,3 \%$. PT. PLN (Persero) Distribusi juga berkomitmen untuk membangun daerah yang memiliki potensi dalam bidang Pariwisata. Salah satunya di Kabupaten Batang. Dengan membantu pariwisata daerah, perusahaan juga bermaksud untuk mendorong perekonomian masyarakat sekitar.

\subsection{Manfaat CSR}

Peneliti juga berusaha mencari tahu manfaat CSR melalui isi berita dengan mengelompokkan berita- berita yang sesuai dengan tolak ukur manfaat CSR. Adapun frekuensi manfaat CSR sebagai berikut :

Tabel 4. Frekuensi Manfaat_CSR

\begin{tabular}{|l|r|r|r|r|}
\hline \multicolumn{1}{|c|}{ Tolak Ukur } & Frequency & Percent & \multicolumn{1}{c|}{$\begin{array}{c}\text { Valid } \\
\text { Percent }\end{array}$} & $\begin{array}{c}\text { Cumulative } \\
\text { Percent }\end{array}$ \\
\hline Valid Akses Terhadap Modal & 2 & 7,1 & 7,1 & 7,1 \\
$\quad$ Meningkatkan Kualitas & 16 & 57,1 & 57,1 & 64,3 \\
$\quad$ Sosial & 10 & 35,7 & 35,7 & 100,0 \\
$\quad \begin{array}{l}\text { Meningkatkan Kualitas } \\
\text { Lingkungan }\end{array}$ & 28 & 100,0 & 100,0 & \\
Total & &
\end{tabular}

Dalam frekuensi tabel manfaat CSR, berita yang menyangkut manfaat dalam meningkatkan kualitas sosial yang berkontribusi untuk pemecahan masalah sosial dan peningkatan kualitas hidup individu, kelompok dan masyarakat paling banyak dilakukan kegiatan CSR yang termuat dalam 16 berita dengan persentasi 57,1\% . Disusul oleh manfaat CSR untuk meningkatkan kualitas lingkungan sebanyak 10 berita dengan persentasi 35,7\%. Manfaat ini bertujuan dalam memberikan daya dukung optimal bagi ke langsungan hidup masyarakat di suatu tempat. Berita mengenai manfaat CSR untuk mendapatkan akses terhadap modal menduduki peringkat ketiga dengan persentasi 7,1\% sebanyak 2 berita saja. Pengembangan Sungai Mudal sebagai sumber potensi wisata di Kulon Progo merupakan suatu modal sosial di masyarakat dan bisa menjadi investasi. Modal sosial tersebut juga dapat membantu mempercepat perbaikan tingkat kesejahteraan masyarakat dan kondisi perekonomian masyarakat. Sedangkan manfaat nomor 3 yaitu meningkatkan nilai perusahaan tidak ada sama sekali

\subsection{Tujuan CSR}

Berita mengenai tujuan CSR paling banyak diduduki oleh nomor 1 yaitu kegiatan CSR yang bertujuan untuk meningkatkan kesejahteraan di masyarakat salah satu contohnya adalah kegiatan pembagian donasi kepada anak yatim piatu senilai Rp. 250 juta. Berita dengan tujuan meningkatkan kesejahteraan masyarakat ini sebanyak 23 berita dengan persentasi $82,1 \%$. 
Tabel 5. Frekuensi Tujuan_CSR

\begin{tabular}{|l|r|r|r|r|}
\hline \multicolumn{1}{|c|}{ Tolak Ukur } & Frequency & Percent & \multicolumn{1}{c|}{$\begin{array}{c}\text { Valid } \\
\text { Percent }\end{array}$} & $\begin{array}{c}\text { Cumulative } \\
\text { Percent }\end{array}$ \\
\hline $\begin{array}{l}\text { Valid Meningkatkan } \\
\text { Kesejahteraan }\end{array}$ & 23 & 82,1 & 82,1 & 82,1 \\
Menjamin & 2 & 7,1 & 7,1 & 89,3 \\
Kesehatan & 3 & 10,7 & 10,7 & 100,0 \\
Masyarakat & 28 & 100,0 & 100,0 & \\
Pendidikan Merata & & & & \\
Total & & & \\
\hline
\end{tabular}

Tolak ukur nomor 2 yaitu tujuan untuk meningkatkan kesehatan masyarakat terdiri atas 2 berita dan persentasi 7,1\%. Tujuan nomor 4 yakni pendidikan merata menduduki posisi kedua sebanyak 3 berita dengan persentasi 10,7\%. Program pendidikan untuk mewujudkan kualitas pendidikan yang merata dapat di lihat dari kegiatan Perusahaan yang memberikan pelatihan kepada 100 guru honorer. Kegiatan ini bertujuan untuk meningkatkan kualitas proses belajar dan mengajar di sekolah-sekolah. Guru honorer tersebut juga diharapkan memiliki peningkatan pemahaman terhadap perilaku dan sifat murid. Serta dapat melakukan proses mengajar yang menyenangkan dan memiliki karakter yang kuat.

\subsection{Citra Perusahaan}

Menurut Harrison dalam Mulyadi (2007:3), citra meliputi empat elemen yakni Personality, Reputation, Value dan Corporate identity. Selanjutnya, peneliti memilih Personality dan Reputation sebagai indikator penilaian terhadap citra perusahaan dalam tabel matriks sebagai berikut :

Tabel 6. Matriks Citra Perusahaan

\begin{tabular}{|c|c|c|}
\hline Variabel & Indikator & TolakUkur \\
\hline \multirow[t]{8}{*}{ Otra Penushasan } & \multirow[t]{4}{*}{ Q. Personalty } & $\begin{array}{l}\text { 1. Pensahaan memilik } \\
\text { Tanogunglawab } \\
\text { Sosial }\end{array}$ \\
\hline & & $\begin{array}{l}\text { 2. Pensshaan dapt } \\
\text { diperctaya }\end{array}$ \\
\hline & & 3. VisidnMisi \\
\hline & & 4. Penghargaan \\
\hline & \multirow[t]{4}{*}{ b. Peputotion } & $\begin{array}{l}\text { 1. Pedulikepada } \\
\text { Pelangran }\end{array}$ \\
\hline & & $\begin{array}{l}2 \text { Kinejapelayinan } \\
\text { baik }\end{array}$ \\
\hline & & $\begin{array}{l}\text { 3. Pensshasan } \\
\text { Ingratif }\end{array}$ \\
\hline & & $\begin{array}{l}\text { 4. Responsif } \\
\text { terhadaplingrungan }\end{array}$ \\
\hline
\end{tabular}




\subsection{Personality}

Indikator Personality meliputi keseluruhan karakteristik yang dipahami oleh publik sasaran seperti perusahaan yang dapat dipercaya dan perusahaan mempunyai tanggung jawab sosial.

Tabel 7 Frekuensi Personality

\begin{tabular}{|l|r|r|r|r|}
\hline Tolak Ukur & Frequency & Percent & Valid Percent & $\begin{array}{c}\text { Cumulative } \\
\text { Percent }\end{array}$ \\
\hline Valid Perusahaan Memiliki & 22 & 78,6 & 78,6 & 78,6 \\
Tanggung.amab Sosial & 3 & 10,7 & 10,7 & 89,3 \\
Visi danMisi & 3 & 10,7 & 10,7 & 100,0 \\
Penghargaan & 28 & 100,0 & 100,0 & \\
Total & & & \\
\hline
\end{tabular}

Dalam indikator Personality, peneliti menilai bahwa hampir seluruh kegiatan CSR yang dilakukan oleh perusahaan dikarenakan perusahaan memiliki tanggung jawab sosial. Tanggung jawab sosial yang tercantum dalam Peraturan Menteri Negara Badan Usaha Milik Negara Nomor Per- 5/MBU.2007 tentang Program Kemitraan BUMN dengan Usaha Kecil dan Program Bina Lingkungan, khusus untuk perusahaan-perusahaan BUMN mengenai kewajiban menjalankan PKBL atau Program Kemitraan Bina Lingkungan inilah yang menjadi landasan PT. PLN (Persero) Distribusi Jateng dan D.I.Y melakukan berbagai kegiatan di masyarakat. Rasa memiliki tanggung jawab sosial ini dapat terlihat dari isi 22 berita dengan persentase 78,6\%. Disusul dengan berita penghargaan dan kegiatan yang berlandaskan visi - misi perusahaan masing-masing sebanyak 3 berita dengan persentase sama yaitu 10,7\%. Sedangkan tolak ukur nomor 2 yaitu perusahaan dapat dipercaya, tidak mendapatkan berita sama sekali.

\subsection{Reputation}

Indikator Reputation terkait dengan hal yang telah dilakukan perusahaan dan diyakini publik sasaran berdasarkan pengalaman sendiri maupun pihak lain. Berikut merupakan frekuensi pada indikator Reputation :

Tabel 8. Frekuensi Reputation

\begin{tabular}{|l|r|r|r|r|}
\hline Tolak Ulkur & Frequency & Percent & \multicolumn{1}{c|}{$\begin{array}{c}\text { Valid } \\
\text { Percent }\end{array}$} & $\begin{array}{c}\text { Cumulative } \\
\text { Percent }\end{array}$ \\
\hline Valid Pedull kepada & 9 & 32,1 & 32,1 & 32,1 \\
Pelanggan & 3 & 10,7 & 10,7 & 42,9 \\
Kinerja Pelayanan Baik & 2 & 7,1 & 7,1 & 50,0 \\
Perusahaan Innovatif & 14 & 50,0 & 50,0 & 100,0 \\
Responsif terhadap & 28 & 100,0 & 100,0 & \\
Linghungan & & & \\
Total & & & \\
\hline
\end{tabular}


Dalam hal Reputation, berita-berita mengenai tanggap atau responsifnya perusahaan terhadap lingkungan yang mencakup bencana maupun kebutuhan masyarakat begitu mendominasi dengan 14 berita berikut persentase sebanyak 50\%. Yang kedua diduduki oleh tolak ukur nomor 1 yaitu kepedulian perusahaan terhadap pelanggan dengan 9 berita dan persentasi $32 \%$. Kepedulian perusahaan terhadap pelanggan dapat dilihat dari salah satu contoh isi berita yang memuat komitmen PT. PLN (Persero) Distribusi Jawa Tengah dan D.I.Y dalam mengaliri listrik ke lebih dari 1000 desa hingga tahun 2019 dan perusahaan membantu UKM masyarakat

Berita menyangkut kinerja pelayanan PLN yang baik juga terdapat 3 berita dengan persentase $10,7 \%$ dan tolak ukur perusahaan yang inovatif terdiri atas 2 berita dengan persentase $7,1 \%$. Perusahaan yang inovatif dapat dilihat dari program CSR yang mendapatkan penghargaan dari pemerintah karena dapat mengembangkan potensi wisata sekaligus kesejahteraan sosial dan lingkungan di masyarakat.

\section{Uji Hipotesis}

\section{Kecenderungan Isi Berita}

\section{a. Corporate Social Responsibility}

Pada variabel CSR, kecenderungan isi berita terdiri atas Program CSR yang paling banyak diberitakan dengan 13 berita dan persentase sebanyak 46,4 \%. Kemudian disusul berita mengenai Tanggung Jawab Perusahaan sebanyak 9 berita dengan 32.2 \%. Berita terkait Tujuan CSR sebesar 14.3\% dan terakhir terkait Manfaat CSR sebanyak 2 berita dengan persentasi 7,1\%. Artinya kecenderungan isi berita pada variabel CSR paling banyak mengenai program-program CSR PT. PLN (Persero) Distribusi Jawa Tengah dan D.I.Y.

\section{b. Citra Perusahaan}

Sedangkan pada variabel Citra Perusahaan, terdiri atas berita terkait Reputation sebanyak 19 berita dengan 67, 8 \% dan terkait Personality sebanyak 9 berita dengan $32,1 \%$. Artinya kecenderungan isi berita dengan variabel Citra Perusahaan paling banyak terkait dengan indikator Reputation. 


\section{Hubungan Berita Kegiatan CSR terhadap Citra Perusahaan}

Pada penelitian ini peneliti membuat analisis isi mengenai isi pemberitaan media online daerah tribunjateng.com terkait Corporate Social Responsibility sebuah perusahaan. Peneliti ingin mencari tahu kecenderungan isi berita CSR pada media online tersebut dan hubungannya dengan citra perusahaan. Hipotesis yang peneliti ajukan ialah sebagai berikut :

$\mathrm{H}_{0}$ : Tidak ada hubungan antara berita kegiatan CSR dengan citra perusahaan $\mathrm{H}_{\mathrm{a}}$ : Terdapat hubungan antara berita kegiatan CSR dengan citra perusahaan

Dasar pengambilan keputusan pada Koefisien Kontingensi: Jika probabilitas $>0,05$, maka $\mathrm{H}_{0}$ diterima. Sementara jika probabilitas $<0,05$, maka $\mathrm{H}_{0}$ ditolak. Langkah pertama yang peneliti persiapkan adalah frekuensi yang dapat di observasi $(0)$, yaitu berupa seluruh berita CSR PT. PLN (Persero) Distribusi Jawa Tengah dan D.I.Y sebanyak 28 berita.Data-data tersebut dihitung melalui program SPSS dengan menggunakan rumus Chi-square.

Berikut merupakan hasil penghitungan menggunakan chi-square dengan crosstabs:

Tabel 9. Case Processing Summary

\begin{tabular}{|c|c|c|c|c|c|c|}
\hline & \multicolumn{6}{|c|}{ Cares } \\
\hline & \multicolumn{2}{|c|}{ Valid } & \multicolumn{2}{|c|}{ Missing } & \multicolumn{2}{|c|}{ Total } \\
\hline & $\mathrm{N}$ & Percent & $\mathrm{N}$ & Perctent: & $N$ & Percent \\
\hline $\begin{array}{l}\text { Variabel_Berita CSRA" } \\
\text { Variabel_Qtra_Perusahaan }\end{array}$ & 20 & $100,0 \%$ & 0 & $0,0 \%$ & 28 & $100,0 \%$ \\
\hline
\end{tabular}

Pada output crosstabs bagian pertama (Case Processing Summary) ada 28 data yang diproses dan tidak ada satupun yang terlewat (missing) sehingga tingkat kevalidannya $100 \%$.

Tabel 10 Berita CSR * Citra_Perusahaan Crosstabulation

\begin{tabular}{|c|r|r|r|}
\hline \multirow{2}{*}{ Indikator Berita CSR } & \multicolumn{2}{|c|}{ Citra_Perusahaan } & \multirow{2}{*}{ Total } \\
\cline { 2 - 4 } CSR Tersonolity & Reputotion & Tonggung Jawab CSR \\
Program CSR & 4 & 5 & 9 \\
& 4 & 9 & 13 \\
Manfaat CSR & 0 & 2 & 2 \\
Tujuan CSR & 1 & 3 & 4 \\
Total & 9 & 19 & 28 \\
\hline
\end{tabular}


Output bagian kedua (Tabel 12) merupakan crosstabs antara variabel berita Corporate Social Responsibility dengan variabel Citra Perusahaan. Pada bagian rows terdapat variabel berita CSR yang terdiri atas Tanggung Jawab, Program, Manfaat serta Tujuan dari CSR kemudian disilangkan kepada columns dari Personality dan Reputation. Pada tabel crosstabs tersebut menjabarkan bahwa :

1. Berita CSR yang erat kaitannya dengan tanggung jawab terdapat 9 berita dengan pembagian masing-masing berkenaan dengan Personality perusahaan sebanyak 4 berita dan 5 berita berhubungan dengan variabel Reputation.

2. Pemberitaan mengenai program-program CSR terdiri atas 13 berita dengan keterkaitan hubungan berita dengan indikatorPersonality perusahaan sebanyak 4 buah dan hubungan dengan indikator Reputation sebanyak 9 berita.

3. Berita yang berisi manfaat CSR berhubungan dengan indikator Reputation hanya sebanyak 2 berita dan tidak ada hubungan lain dengan indikator Personality.

4. Hubungan berita mengenai Tujuan CSR dengan indikator Reputation sebanyak 3 berita dan Personality sebanyak 1 berita sehingga total terdapat 4 berita.

Kemudian data pada Crosstabs tersebut digunakan untuk penghitungan Chi square yang dapat dilihat pada output bagian ketiga.

\section{Tabel 11 Chi-Square Tests}

\begin{tabular}{|l|r|r|r|}
\hline & Value & \multicolumn{1}{|c|}{ of } & Asymp. Sig (2-sided) \\
\hline Pearson Chi.Square & 1,677 & 3 &, 642 \\
Uikelihood Ratio & 2,252 & 3 &, 522 \\
Uinear-by.Uinear &, 884 & 1 &, 347 \\
Association & 28 & & \\
Nof Valid Cases & & \\
\hline
\end{tabular}

Pada value Chi-square hitung bagian Pearson Chi Square adalah 1,677 dengan Tingkat Signifikasi (a) yang ditetapkan pada program SPSS $=5 \%$. Derajat kebebasan (df) sebesar 3. Derajat kebebasan dihasilkan dari (jumlah baris-1) $\times$ (jumlah kolom-1). Karena ada 4 baris dan 2 kolom, maka $\mathrm{df}=(4-1) \times(2-1)=3$. Output SPSS otomatis menyatakan bahwa derajat kebebasan (df) adalah 3. Hipotesis untuk kasus ini :

$\mathrm{H}_{0}$ : Tidak ada hubungan antara berita kegiatan CSR dengan citra perusahaan $\mathrm{Ha}$ : Terdapat hubungan antara berita kegiatan CSR dengan citra perusahaan

Pengambilan keputusan berdasarkan nilai (value) ChiSquare dengan derajat kebebasan (df) yaitu 3 dan taraf signifikansi 5\%, maka pada Tabel Nilai Kritis Chi Square (lampiran 2), nilai yang digunakan sebesar 7,814. Nilai (value) Chi Square yang didapat pada Tabel 4.13 dalam Pearson Chi Square menunjukkan value sebesar 1,677 atau di bawah 7,814 $(1,677<7,814)$, maka hipotesis "Tidak ada hubungan antara kegiatan CSR dengan Citra Perusahaan" atau $\mathbf{H}_{\mathbf{0}}$ diterima. 


\section{Uji Hubungan}

Tabel 12 Koefisien Kontingensi (Contingency Coefficient)

\begin{tabular}{|c|c|c|c|c|c|}
\hline & & Vylue & $\begin{array}{l}\text { Asymp. Sod } \\
\text { Empec }\end{array}$ & $\begin{array}{c}\text { Aeprak } \\
T^{2}\end{array}$ & $\begin{array}{l}\text { Approx. } \\
\text { saz. }\end{array}$ \\
\hline $\begin{array}{l}\text { Nominal by } \\
\text { Nominal }\end{array}$ & $\begin{array}{l}\text { Cortingency } \\
\text { Coffticiert }\end{array}$ & , 238 & & & .642 \\
\hline Interval by interval & Pearson's R & , 191 & .180 & ,930 & $.35 \mathrm{~N}$ \\
\hline $\begin{array}{l}\text { Ondinal by Ordnal } \\
\text { Nof ValidCones }\end{array}$ & $\begin{array}{l}\text { Sperman } \\
\text { Comelaisn }\end{array}$ & .204 & 182 & 1,061 & $2999^{\circ}$ \\
\hline
\end{tabular}

Pada output Tabel 14, kolom value Contingency Coefficient menunjukkan angka 0,238. Dengan demikian, kekuatan hubungan antara berita kegiatan Corporate Social Responsibility dengan Citra Perusahaan sangat lemah berdasarkan pada kriteria Koefisien Korelasi (lampiran 3). Selanjutnya, peneliti berusaha untuk mengetahui hubungan antara variabel dengan nilai probabilitasnya. Hipotesis untuk kasus ini :

$\mathrm{H}_{0}$ : Tidak ada hubungan antara berita kegiatan CSR dengan citra perusahaan

$\mathrm{Ha}$ : Terdapat hubungan antara berita kegiatan CSR dengan citra perusahaan

Dasar pengambilan keputusan: Jika probabilitas $>0,05$, maka $\mathrm{H}_{0}$ diterima. Sementara jika probabilitas < 0,05, maka $\mathrm{H}_{0}$ ditolak. Pada tabel Chi Square bagian Asymp. Sig. (tabel 4.13) menunjukkan angka yaitu 0,642. Hasil pada Asymp.Sig tersebut sama dengan Approx.Sig pada Contingency Coefficient (tabel 4.14). Maka, keputusan yang diambil sesuai dengan yang terlihat pada Asymp.sig dan Approx.sig adalah 0,642 atau Probabilitas di atas 0,05 (0,642 > 0,05), jadi $\mathbf{H}_{\mathbf{0}}$ diterima. Bisa diambil kesimpulan yang sama bahwa Tidak ada hubungan antara berita kegiatan CSR dengan Citra Perusahaan.

Kegiatan Corporate Social Responsibility yang dilakukan oleh PT. PLN Persero Distribusi Jawa Tengah dan D.I.Y yang tertuang dalam isi berita CSR pada media online Tribunjateng.com sangat erat kaitannya dengan 3 dari lima tipologi tersebut. Ketiga tipologi tersebut yakni

1. Strategi ingratiation (menyenangkan orang lain). PT. PLN (Persero) Distribusi Jawa Tengah dan D.I.Y berusaha untuk menjadi dekat dengan pelanggan-pelanggan mereka dan berusaha untuk reponsif terhadap apa yang terjadi dengan masyarakat. Salah satu contohnya PLN berusaha untuk membantu masyarakat yang membutuhkan dengan membagikan sembako dan uang untuk keperluan pembelian kebutuhan sehari-hari menjelang bulan Ramadhan. PT. PLN (Persero) juga berusaha untuk membantu usaha kecil menengah (UMKM) kepada masyarakat dengan memberikan modal bahkan menolong usaha kedelai pelanggannya yang nyaris bangkrut. Semua usaha diatas tak lain adalah upaya PT. PLN (Persero) Distribusi Jawa Tengah dengan strategi ingratiation.

2. Strategi self-promotion (promosi diri). Pada strategi ini, perusahaan PLN berusaha untuk 
menampilkan prestasi dan hal-hal baik yang telah mereka capai kepada publik agar dianggap sebagai organisasi yang kompeten. Salah satu contohnya adalah berita yang membahas prestasi PT. PLN setelah penyelamatan sumber daya alam dengan menjaga sumber air sungai mudal. CSR yang telah dilakukan ini dapat menciptakan kawasankawasan yang unggul dalam pelestarian lingkungan dan pemberdayaan ekonomi sosial di masyarakat serta telah peduli pada investasi sosial dan pembangunan yang berkelanjutan. Bahkan, dengan program CSR ini, PT. PLN (Persero) Distribusi Jawa Tengah mendapatkan penghargaan Indonesia Green Award. Tidak hanya itu, perusahaan ini juga mendapatkan penghargaan dari pemerintah Kota Semarang karena turut serta melestarikan Batik Semarangan.

Ajang promosi diri tidak pula hanya berupa prestasi dan penghargaan saja namun dapat berupa hal-hal baik salah satu contohnya PT. PLN (Persero) Distribusi Jawa Tengah berusaha untuk mengembangkan 3 pariwisata di daerah Kabupaten Batang. Tidak tanggung-tanggung, perusahaan ini menggelontorkan Rp.400 juta dan dan total CSR senilai 9 Miliar hingga tahun 2017. Hal ini dikonfirmasi langsung oleh Hadian Sakti Laksana, Deputi Manajer Komunikasi dan Bina Lingkungan PT PLN (Persero) Distribusi Jateng dan D.I.Y. Semua hal itu dilakukan guna memberikan investasi dan modal yang berkelanjutan bagi perusahaan sendiri maupun masyarakat kedepannya. Dengan adanya pemberian akses modal dan investasi kepada masyarakat, sekaligus program ini berdampak pada ajang promosi perusahaan karena turut serta membangun daerah untuk perekonomian berkelanjutan.

3. Strategi exemplification (sebagai contoh), pada tahap ini, sebuah organisasi atau perusahaan berusaha untuk menampilkan hal-hal yang bagus agar dapat dijadikan contoh oleh organisasi/perusahaan lain. Hal ini dapat membuat sebuah organisasi dipandang kompeten. Salah satu contoh dimana PT. PLN (Persero) Distribusi Jawa Tengah dan D.I.Y dapat dijadikan contoh adalah ketika perusahaan ini begitu responsif terhadap lingkungan. PT. PLN (Persero) Distribusi Jawa Tengah dan D.I.Y mengerahkan 115 personil untuk mengatasi gangguan di 46 desa pada hari dimana gangguan itu terjadi. Tindakan yang dilakukan oleh perusahaan ini dapat dijadikan contoh oleh organisasi lain terkait cepatnya pengatasan masalah yang menyangkut pelanggan dan masyarakat sekitar.

Sedangkan kecenderungan isi berita pada indikator Citra Perusahaan paling banyak berkaitan dengan indikator Reputation dibandingkan indikator Personality. Terdapat 19 berita dengan isi mengacu pada indikator Reputation dan persentasi sebesar $67,8 \%$. Personality berkaitan dengan keseluruhan karakteristik yang dipahami oleh publik sasaran seperti perusahaan yang dapat dipercaya dan perusahaan mempunyai tanggung jawab sosial, sedangkan Reputation adalah persepsi publik mengenai tindakan-tindakan 
organisasi yang telah berlalu dan prospek organisasi di masa datang.

Pada hasil penelitian diatas, terlihat bahwa kecenderungan isi berita pada Indikator Citra Perusahaan diduduki oleh indikator Reputation. Indikator Reputation lebih menekankan pada kepedulian perusahaan terhadap pelanggan, pelayanan yang cepat tanggap terutama pada keluhan dan kegiatan perusahaan yang inovatif. Salah satu contohnya ketika PT. PLN (Persero) segera menangani gangguan yang terjadi di daerah Kebumen dengan menerjunkan 115 Personel untuk memperbaiki kerusakan diakibatkan terputusnya jaringan listrik karena angin kencang. Kesigapan ini tak lain sebagai bentuk pelayanan yang baik perusahaan terhadap keluhan pelanggan.

PT. PLN (Persero) Distribusi Jawa Tengah dan D.I.Y telah melakukan ajang promosi diri dengan baik dan mendapatkan tanggapan yang baik pula dari masyarakat melalui data penelitian. Semua isi berita dapat menjawab indikator CSR maupun Citra Perusahaan dengan cukup baik. Namun, pada tingkat hubungan diketahui bahwa tidak ada hubungan antara program CSR yang terangkum dalam berita selama tahun 2017 hingga kuartal pertama tahun 2018 oleh tribunjateng.com dengan Citra perusahaan. Hal ini dapat dibuktikan dengan nilai dari Chi Square lebih kecil dibandingkan nilai pada Tabel Kritis yaitu sebesar 1,677<7,814.

Sedangkan kekuatan hubungan dua variabel pun sangat lemah dibutikan dengan nilai Koefisien Kontingensi sebesar 0,238. Adapun pada nilai probabilitasnya, tingkat signifikansi pada Pearson Chi-Square dan Koefisien Kontingensi sama yaitu 0,642 >0,05, sehingga tidak adanya hubungan antara kedua variabel. Hal ini bertentangan dengan teori yang diajukan bahwa CSR dapat meningkatkan dan mempengaruhi Citra suatu perusahaan. Tidak adanya hubungan antara CSR dengan Citra Perusahaan dapat dipengaruhi oleh faktor-faktor lain di luar objek penelitian. Selain itu, meningkatnya citra positif terhadap suatu perusahaan juga dapat diakibatkan oleh faktor-faktor lain selain berita kegiatan CSR.

\section{Simpulan}

PT PLN Distribusi Jawa Tengah dan DIP berupaya menampilkan citra melalui pemberitaannya. Hal ini dilakukan untuk dapat membentuk opini baik mengenai hal- hal positif, inovatif dan menunjukkan prestasi-prestasi yang baik kepada publik. Salah satu caranya adalah melaksanakan kegiatan Corporate Social Responsibility sekaligus sebagai ajang presentasi diri. Hal ini berkaitan erat dengan teori Manajemen Impresi dalam lingkup profesional organisasi dimana perusahaan berusaha untuk menyebarkan hal positif saja. Hubungan Corporate Social Responsibility yang dilakukan PT. PLN (Persero) Distribusi Jawa Tengah dan D.I.Y dengan Citra Perusahaan melalui pemberitaan di media massa online Tribunjateng.com menunjukkan bahwa kecenderungan isi berita pada variabel CSR paling banyak membahas Program CSR dengan persentasi $46,4 \%$ sebanyak 13 berita. Sedangkan pada variabel Citra Perusahaan, 
kecenderungan isi berita pada indikator Reputation dengan 19 berita dan persentasi 67,8\%. Kekuatan hubungan antara dua variabel sangat lemah diketahui berdasarkan hasil Koefisien Kontingensi sebesar 0,238 . Hasil penelitian juga menunjukkan tidak adanya hubungan antara kegiatan CSR dengan Citra Perusahaan dengan Probabilitas Asymp. Sig dan Approx Sig. sebesar $0,642>0,05$ sehingga HO diterima.

\section{Daftar Pustaka}

\section{Buku :}

Ardianto, Elvinaro. (2011). Handbook of Public Relations. Bandung: Simbiosa Rekatama Media. Butterick, Keith. (2012). Pengantar Public Relation : Teori dan Praktik. PT. Raja Grafindo Persada. Jakarta.

Effendy, Onong Uchjana. (2003) IImu, Teori dan Filsafat Komunikasi. Bandung : Citra Aditya Bakti.

Eriyanto, (2011). Analisis Isi: Pengantar Metodologi untuk Penelitian IImu Komunikasi dan IImu- IImu Sosial Lainnya. Jakarta: Kencana Prenada Media Group.

Fombrun, C.J. (1996) Reputation - Realising Value From Corporate Image. Harvard Business Review

Jefkins, Frank. (2003). Public Relations. Jakarta : Erlangga.

Jefkins, \& Yadin. (2003). Public Relations Edisi kelima. Jakarta: Penerbit Erlangga

Kriyantono, Rachmat. (2017). Teori-Teori Public Relations Perspektif Barat \& Lokal: Aplikasi Penelitian dan Praktik. Jakarta : Kencana

Mulyadi. (2007). Sistem Perencanaan dan Pengendalian manajemen, Edisi Ketiga, Jakarta: Salemba Empat

Oliver, Sandra. (2007) PR Strategy, second edition, CIPR Chartered Institute of Public Relation, London and Philadelphia

Richard West, Lynn H.Turner. (2008) Pengantar Teori Komunikasi: Analisis dan Aplikasi (Buku 2) (Edisi 3) Jakarta: Salemba Humanika

Ruslan,Rosady.(2008). Manajemen Public Relatoins \& Media Komunikasi. Jakarta : PT Rajagrafindo Persada.

Soleh Soemirat, dan Ardianto.(2002). Dasar-dasar Public Relations. Bandung : PT Remaja Rosda Karya

Sugiyono.(2007). Metodologi Penelitian Bisnis, PT. Gramedia, Jakarta Sugiyono.(2012). Metode Penelitian Kuantitatif Kualitatif dan R\&B. Bandung: Alfabeta. Sutojo, Siswanto. (2004). Membangun Citra Perusahaan. Jakarta: PT Damar 


\section{Jurnal :}

Ardianto, Elvinaro. (2012). Analisis Wacana Kritis Pemberitaan Harian Pikiran Rakyat dan Harian Kompas Sebagai Public Relations Politik dalam Membentuk Branding Reputation Presiden Susilo Bambang Yudhoyono. Jurnal IImu Komunikasi Sunan Ampel Surabaya. ISSN. 2088- 981X. Volume2. Nomor 1. HIm. 15-52.

Bortree, D. S. (2014). The state of csr communication research: a summary and future direction. Public Relations Journal, 8 (3), hlm. 1-8.

Haniffa, R.M., dan Krishna G. Palepu (2005), " The impact of Culture and Governance on Corporate Social Repsonsibility". Journal of Accounting and Public Policy 24, Hal 391-430 Podnar, Klement. (2008) Communicating Corporate Social responsibility. Journal of Marketing Communications, Vol. 14 No.2 (2008) Hal. 75

\section{Skripsi :}

Mutmainah, Siti. (2011) . Manajemen Impresi Perusahaan Rokok : Kajian Atas Pelaporan Sampoerna Pada Website Dengan Model SMCR Berlo. Jurnal Akuntansi Multiparadigma, 2 (2) Hal 186-368

\section{Artikel :}

Rezkisari, Indira.Abaikan CSR, Marwan Ganjar Sanksi Bagi Perusahaan, http://www.republika. co.id, diakses pada 4 Maret 2018 pada pukul13.02 WIB

Raka F. PLN Salurkan Rp.400 Juta untuk Dorong Tiga Tempat Wisata Ini, http://jateng. tribunnews.com, diakses pada 4 Maret 2018 pada pukul 13.25 WIB 